E3S Web of Conferences 1, 14001 (2013)

DOI: $10.1051 / \mathrm{e} 3$ sconf/20130114001

(c) Owned by the authors, published by EDP Sciences, 2013

\title{
Historical reconstruction of Plutonium contamination in the Swiss-Italian Alps
}

\author{
J. Gabrieli ${ }^{1}$, G. Cozzi ${ }^{1}$, P. Vallelonga ${ }^{5}$, M. Schwikowski ${ }^{3}$, M. Sigl ${ }^{3}$, C. Boutron ${ }^{4}$ and C. Barbante ${ }^{1,2}$ \\ ${ }^{1}$ Institute for the Dynamics of Environmental Processes IDPA-CNR, 30123 Venice, Italy, jacopo.gabrieli@idpa.cnr.it \\ ${ }^{2}$ Department of Environmental Sciences, Informatics and Statistics, University Ca' Foscari of Venice, 30123 Venice, \\ Italy \\ ${ }^{3}$ Paul Scherrer Institut, 5232 Villigen (PSI), Switzerland \\ ${ }^{4}$ Laboratoire de Glaciologie et Géophysique de I'Environnement (LGGE), University Joseph Fourier of Grenoble, 38402 \\ St Martin d'Hères Cedex, France \\ ${ }^{5}$ Centre for Ice and Climate - Niels Bohr Institute, University of Copenhagen, DK-2100 Copenhagen, Denmark
}

\begin{abstract}
Plutonium is present in the environment as a consequence of atmospheric nuclear tests carried out in the 1960s, nuclear weapons production and releases by the nuclear industry over the past 50 years. Approximately 6 tons of ${ }^{239} \mathrm{Pu}$ have been released into the environment as a result of 541 atmospheric weapon tests Nuclear Pu fallout has been studied in various environmental archives, such as sediments, soil and herbarium grass. Mid-latitude ice cores have been studied as well, on Mont Blanc, the Western Alps and on Belukha Glacier, Siberian Altai. We present a Pu record obtained by analyzing 52 discrete samples of an alpine firn/ice core from Colle Gnifetti (M. Rosa, $4450 \mathrm{~m}$ a.s.1.), dating from 1945 to 1991 . The ${ }^{239} \mathrm{Pu}$ signal was recorded directly, without preliminary cleaning or preconcentration steps, using an high resolution inductively plasma mass spectrometer equipped with a desolvation system. The ${ }^{239} \mathrm{Pu}$ profile reflects the three main periods of atmospheric nuclear weapons testing: the earliest peak lasted from 1954/55 to 1958 and was caused by the first testing period reaching a maximum in 1958. Despite a temporary halt of testing in 1959/60, the Pu concentration decreased only by half with respect to the 1958 peak due to long atmospheric residence times. In 1961/62 Pu concentrations rapidly increased reaching a maximum in 1963. After the signing of the "Limited Test Ban Treaty" between USA and USSR in 1964, Pu deposition decreased very sharply reaching a minimum in 1967. The third period (1967-1975) is characterized by irregular Pu concentrations with smaller peaks which might be related to the deposition of Saharan dust contaminated by the French nuclear tests of the 1960s.
\end{abstract}

Key words: Plutonium, Alps, ice, snow, ICP-SFMS, nuclear tests

\section{Introduction}

Plutonium is present in the environment as a consequence of the atmospheric nuclear tests carried out since the 1950 s as well as the production of nuclear weapons and industrial releases over the past 60 years. Plutonium is not naturally present on Earth, and was first artificially produced and isolated in 1940 by deuteron bombardment of uranium in the cyclotron of Berkeley University. It exists as five main isotopes, ${ }^{238} \mathrm{Pu},{ }^{239} \mathrm{Pu},{ }^{240} \mathrm{Pu},{ }^{241} \mathrm{Pu}$, ${ }^{242} \mathrm{Pu}$, derived from civilian and military sources (weapons production and detonation, nuclear reactors, nuclear accidents), of which ${ }^{239} \mathrm{Pu}$ is the most abundant in the environment. It was estimated that approximately 6 tons of ${ }^{239} \mathrm{Pu}$ were released into the environment as a result of 541 atmospheric weapon tests (Carter and
Moghissi, 1977). On 30th October 1961, over the Arctic, the Soviet Union detonated the $50 \mathrm{Mt}$ TNT equivalent "Tsar Bomb", the most powerful nuclear weapon ever built, about 4000 times more powerful than the bombs detonated in Hiroshima and Nagasaki. In 1963 the USSR and USA signed the "Limited Test Ban Treaty" in which they committed themselves to stop all above-ground nuclear tests. From then, until 1980, only 64 aboveground nuclear explosions occurred, all of them carried out by France (41) and China (23) (Lawson, 1998). Polar and mid-latitude mountain glaciers are particularly important for studying the anthropogenic impact on the environment during the last decades because they allow highly resolved temporal records (Barbante et al., 2011). The extremely low concentrations of $\mathrm{Pu}$ in glacial ice require demanding analytical techniques with very 

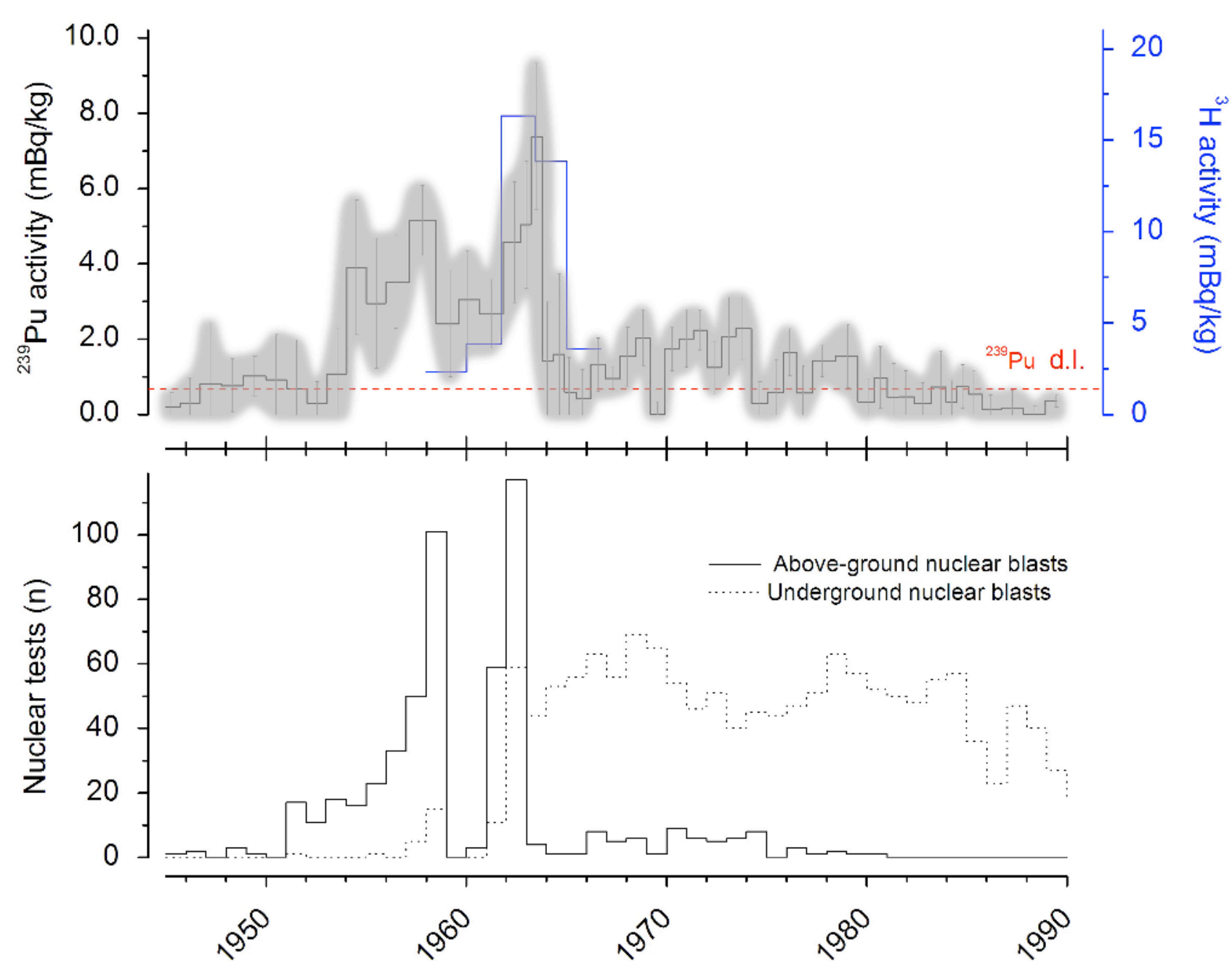

Calendar year

Fig. $1{ }^{239} \mathrm{Pu}$ activities, with the associated RSD (gray shadding), in the upper $31 \mathrm{~m}$ of firn and ice from Monte Rosa and five ${ }^{3} \mathrm{H}$ measurments (blu line), corresponding approximately to the time period 1945-1990, compared with the number of worldwide nuclear tests (solid line: atmospheric tests; dotted line: underground tests)

sensitive instrumentation and/or large sample amounts for accurate determination (Olivier et al., 2004).We present here a high-resolution profile of atmospheric ${ }^{239} \mathrm{Pu}$ deposition reconstructed from an ice core collected on Colle Gnifetti in the Monte Rosa massif (Swiss/Italian Alps, $4450 \mathrm{~m} \mathrm{asl).}{ }^{239} \mathrm{Pu}$ was analyzed directly by Inductively Coupled Plasma-Sector Field Mass Spectrometry (ICP-SFMS) equipped with a desolvation system without need for any pre-concentration or sample clean-up steps.

\section{Materials and Methods}

In September 2003, two firn/ice cores, respectively 81.9 and $81.1 \mathrm{~m}$ long, were drilled to the bedrock on Colle Gnifetti (4455 m a.s.1., 45 $\left.55^{\prime} 50.4^{\prime \prime} \mathrm{N}, 07^{\circ} 52^{\prime} 33.5^{\prime \prime} \mathrm{E}\right)$, Monte Rosa massif, near the Swiss/Italian border. The dating was performed by combining annual layer counting (back to 1766 AD) with the identification of
Saharan dust strata (1977, 1947, 19361901 AD), volcanic eruptions (Katmai, 1911 AD; Laki, 1783 AD), and the tritium horizon (1963 AD) as well as radiocarbon measurements (Jenk et al., 2009). The core was transported frozen to the University of Venice where it was processed in a $-20{ }^{\circ} \mathrm{C}$ cold room. ${ }^{239} \mathrm{Pu}$ was determined in 52 discrete samples dating from 1945 to 1990 AD by ICP-SFMS direct analysis, using an Element2 ICP-SFMS (Thermo Scientific, Bremen, Germany) in low resolution mode and coupled to an Apex Q high efficiency sample introduction system (Elemental Scientific, Omaha, NE, USA) to achieve the maximum instrumental sensitivity. An indirect calibration of ${ }^{239} \mathrm{Pu}$ with ${ }^{238} \mathrm{U}$ was applied using an external calibration curve. For the external calibration of $\mathrm{Pu}$, solutions of ${ }^{238} \mathrm{U}$ were prepared from a $10 \mu \mathrm{g} \mathrm{g}^{-1}$ multielemental ICP-MS stock solution in $2 \%(\mathrm{v} / \mathrm{v}) \mathrm{HNO}_{3}$ acidified ultrapure water. The ${ }^{238} \mathrm{U}$ concentrations in the final standard solutions were $0.2,0.5,1.0$, and $5.0 \mathrm{pg} \mathrm{g}^{-1}$. 
This approach is valid as a first approximation because the sensitivity of heavy elements in ICP-SFMS is strongly correlated to their masses. Moreover, the first ionization energy for $\mathrm{Pu}$ and $\mathrm{U}$ are very close $(6.06 \mathrm{eV}$ and $6.19 \mathrm{eV}$, respectively) and for this reason they should have a similar behavior when ionized in the plasma. Finally, snow and ice can be considered a relatively pure environmental matrix and hence no element-specific matrix effects should be expected for heavy elements. The ${ }^{239} \mathrm{Pu}$ concentrations calculated by this semiquantitative method has been expressed both in mass and activity units, using the specific activity value for ${ }^{239} \mathrm{Pu}$ (2.29 $\left.\times 10^{9} \mathrm{~Bq} \mathrm{~g}^{-1}\right)$, as reported in Baglan et al. (2000). The blank values were calculated by analyzing ice samples dated before 1940 s, which are assumed to be free from $\mathrm{Pu}$ contamination, obtaining a mean value of $0.03 \pm 0.07 \mathrm{fg} \mathrm{g}^{-1}$. The detection limit, calculated as three times the standard deviation of the blanks, was $0.2 \mathrm{fg} \mathrm{g}^{-1}$ (corresponding to $0.6 \mathrm{mBq} \mathrm{kg}{ }^{-1}$ ). The precision (RSD) ranged from 18 to $112 \%$ (mean 46\%) for $\mathrm{Pu}$ concentrations higher than $1.0 \mathrm{fg} \mathrm{\textrm {g } ^ { - 1 }}$ while for concentrations lower than $1.0 \mathrm{fg} \mathrm{g}^{-1}$ precisions were from 34 to $194 \%$ (mean $125 \%$ ).

\section{Results and Discussion}

In Fig. 1, the ${ }^{239} \mathrm{Pu}$ profile inferred from the Colle Gnifetti ice core and the records of atmospheric and underground nuclear tests are reported. $\mathrm{Pu}$ is first detectable in Colle Gnifetti ice in 1954-1955 while activities are constantly less than the instrumental detection limit in earlier samples. The first ${ }^{239} \mathrm{Pu}$ activity peak occurs in $1955 / 56$ with a maximum value of $3.9 \pm 1.8 \mathrm{mBqkg}^{-1}$.

A slight decrease followed, with activities about $2.9 \pm 1.7 \mathrm{mBq} \mathrm{kg}^{-1}$, until a second activity peak of $5.2 \pm 0.9$ $\mathrm{mBq} \mathrm{kg}^{-1}$ was detected in $1958 / 59$. The second peak in $\mathrm{Pu}$ activity is in good agreement with the historical statistics which report 101 atmospheric bomb tests in 1958. In November 1958 the Partial Test Ban Treaty temporarily stopped atmospheric tests, until the resumption of tests by the USSR in September 1961. Despite the temporary halt of testing in $1959 / 60$, the $\mathrm{Pu}$ activity only decreased to half of the value of the 1958 peak due to the long residence time in the atmosphere, reaching $2.4 \pm 1.4 \mathrm{mBq} \mathrm{kg}^{-1}$. With the resumption of tests in 1962 , the $\mathrm{Pu}$ activity rapidly increased to a maximum of $7.4 \pm 1.9 \mathrm{mBq} \mathrm{kg}{ }^{-1}$ in $1963-64$, almost double the intensity of the 1958 peak. In the period 1961/62, 168 atmospheric nuclear weapon tests were carried out by the USA, USSR, France and UK, some of which were extremely powerful. In the same year, the Soviet Army tested the most powerful thermonuclear weapon (Tsar bomb, $57 \mathrm{Mt}$ ). While the maximum numbers of atmospheric tests were recorded in 1958 and 1962, the highest $\mathrm{Pu}$ concentrations in the Colle Gnifetti core were detected in 1959 and 1963, respectively. The shift in the $\mathrm{Pu}$ maxima could be explained by a long residence time due to mixing and transport processes in atmosphere. In 1963 the USA and USSR signed the Limited Test Ban
Treaty, suspending all atmospheric nuclear detonations. Comparing the ${ }^{239} \mathrm{Pu}$ and ${ }^{3} \mathrm{H}$ profiles in the time period from 1958 to 1966 (Fig. 1), the relative intensity of the ${ }^{3} \mathrm{H}$ signal for 1959 is much smaller as compared to $\mathrm{Pu}$. A possible explanation is that the ${ }^{3} \mathrm{H}$ production during the first fission bomb tests period was limited while it considerably increased with the thermonuclear detonation tests. ${ }^{3} \mathrm{H}$ was mainly used in thermonuclear bombs for boosting the primary fission which triggers the fusion process. The ${ }^{239} \mathrm{Pu}$ record shows a better correspondence to the number of atmospheric nuclear tests than ${ }^{3} \mathrm{H}$, which is more related to the nuclear fallout derived by thermonuclear blasts. After 1964, the $\mathrm{Pu}$ activities in Colle Gnifetti core decreased very sharply, reaching an intermediate minimum in 1967 . The period from 19671974 is characterized by an irregular $\mathrm{Pu}$ profile with some peaks of activity values about $20-30 \%$ of the size of the 1964 peak. These secondary peaks should be primarily due to the French and Chinese atmospheric tests carried out during that period, but the observed activities are high relative to the maxima of the 1960s, and cannot be directly related to the number and power of atmospheric tests. From 1960 to 1966, France carried out 17 nuclear tests in two testing sites in the Algerian Sahara desert. Four of them, in 1960-61, were atmospheric tests with a total power of more than $0.07 \mathrm{Mt}$, while the other 13 tests were conducted underground, even though serious breaches of containment of radioactive material have been reported (IAEA, 2005). At the end of 2009, the French parliament approved a law to compensate the victims of the nuclear tests in Algeria and Polynesia, admitting that the health consequences of testing were not negligible. In addition to the serious health effects suffered by the local populations and the military personnel involved, the nuclear fallout contaminated adjacent soils and consequently remobilized desert dust (Baggoura et al., 1998). Since soil scouring by atmospheric wet deposition is very limited in the arid Saharan region, fine radioactive particles can remain in the upper crust for very long times and then be remobilized by winds for transport over long distances. In a recent study carried out by the IAEA in the Algerian desert, it was found that most of the areas at the French test sites have some residual activity and there are even sites where high (Reganne, Taourirt Tan Afellaand) and medium (Taourirt Tan Afella, Adrar Tikertine) radioactivity levels are still present (IAEA, 2005). The relatively high activities of ${ }^{239} \mathrm{Pu}$ in alpine snow dated to the period 1967-1974 may be due to the transport of Saharan dust which was contaminated by French nuclear tests conducted in the 1960s. This hypothesis is supported by $\mathrm{Ca}$ concentrations measured in the samples, which display elevated concentrations in the section corresponding to the periods 1967-1974. In previous studies it was demonstrated that about two-thirds of the deposited dust in the Southern Alps originates from the Saharan desert (Wagenbach and Geis, 1989), especially during spring and summer (Eichler et al., 2004). After the mid-1970s, this effect probably diminished due to 
decreasing radioactivity levels in Saharan dust as a result of erosion and scouring phenomena. After $1975,{ }^{239} \mathrm{Pu}$ activities in the Colle Gnifetti ice core decreased below the instrumental detection limit.

\section{Conclusions}

This research allowed to emphasize how nuclear blasts/experiments carried out since 1940's produced a contamination on a planetary scale. Plutonium concentration profile obtained from Colle Gniffetti ice core shown a clear correlation with the number of worldwide nuclear tests.

The direct analysis of snow/ice using ICP-SFMS is a reliable analytical method to determine Plutonium at sub-ppt levels and this approach could be used also for routine monitoring campaigns.

\section{References}

Baggoura B, Noureddine A, Benkrid M. Level of natural and artificial radioactivity in Algeria. Applied Radiation and Isotopes 1998;49:867-873.

Baglan N, Cossonnet C, Pitet P, Cavadore D, Exmelin L, Berard P. On the use of ICP-MS for measuring plutonium in urine. Journal of Radioanalytical and Nuclear Chemistry 2000;243:397-401.

Barbante C, Gabrieli J, Gabrielli P, Vallelonga P, Cozzi G, Turetta C, Hong S, Rosman K, Boutron C, Cescon P. A hystorical record of heavy metal pollution in Alpine snow and ice. In: Quante, M., Ebingaus, R., Floser, G. (Eds.) Persistent Pollution e
Past, Present, Future. Springer Verlag, Berlin, Germany 2011;93-122.

Carter MW, Moghissi AA. Three decades of nuclear testing. Health Physics 1977;33:55-71.

Eichler A, Schwikowski M, Furger M, Schotterer U, Gaggeler H. Source and distribution of trace species in Alpine precipitation inferred from two 60-years ice core paleorecords. Atmospheric Chemistry and Physics Discussion 2004;4,71-108.

IAEA. Radiological conditions at the former French nuclear test sites in Algeria: preliminary assessment and recommendations. In: Radiological Assessment Reports Series, International Atomic Energy Agency (IAEA). International Atomic Energy Agency (IAEA), Vienna (Austria) 2005.

Jenk T.M., Szidat, S., Bolius, D., Sigl, M., Gaggeler, H.W., Wacker, L., Ruff, M., Barbante, C., Boutron, C.F., Schwikowski, M., 2009. A novel radiocarbon dating technique applied to an ice core from the Alps indicating late Pleistocene ages. Journal of Geophysical Research 114, D14305.

Lawson JE. Catalog of nuclear explosions. Avail. at the web site: http:// www.okgeosurvey1.gov/level2/nuke.cat.index.html 1998.

Wagenbach D, Geis K. The mineral dust record in a high altitude Alpine glacier (Colle Gnifetti, Swiss Alps). In: Leinen M, Sarnthein M. (Eds.), Paleoclimatology and Paleometeorology: Modern and Past Patterns of Global Atmospheric Transport. Kluwer Academic Publishers, Dortrecht, Netherlands 1989;543-564. 